\title{
EFEKTIFITAS PEMBELAJARAN MATA KULIAH AKUNTANSI BISNIS DENGAN PENDEKATAN CONSTRUKTIVIST LEARNING DESIGN (CLD) BERBANTUAN MEDIA E-LEARNING
}

\author{
Iwan Koerniawan, Siti Kholifah \\ Sekolah Tinggi Elektronika dan Komputer \\ iwandanie133@yahoo.com, olivstekom@gmail.com
}

\begin{abstract}
Experience the ability of students using their knowledge have that has to review contruktivist the new knowledge is very media-influenced learning used one solution offered to review follow-up to these problems is a concept learning courses through construktivist business accounting teaching. singer study aims to determine the effectiveness of the learning review accounting subjects based business micruled assisted e-learning yang to review valid student learning. population research hearts hearts singer is whole semester students III study program computerized accounting STEKOM semarang. singer is an experimental research operates quasi experimental research (samsudi, 2006: 75) the review aims to improve student academic achievement on subjects accounting subjects who meet criteria for an effective business. tin research findings: (1) there is a positive effect of process skills against students' learning achievement is shown the effect of 55.6\% contribution. (2) the learning achievement of the experimental classes more than learning achievement high grade control is shown with average - ratany a that is the average - average class experiment at 78 and the average - average grade control 65.7. so based on the findings of the research and discussion research above and learning business accounting subjects with construktivist aided teaching e-learning on business accounting subjects is effective.
\end{abstract}

Keywords: Construktivist Learning Design., E-Learning, Business Accounting

\begin{abstract}
Abstrak
Kemampuan mahasiswa menggunakan pengalaman atau pengetahuan yang telah mereka miliki untuk mengonstruk (membangun) pengetahuan yang baru sangat dipengaruhi media pembelajaran yang digunakan. Salah satu solusi yang ditawarkan untuk menindaklanjuti permasalahan tersebut adalah konsep pembelajaran mata kuliah akuntansi bisnis melalui Construktivist Learning Design. Penelitian ini bertujuan untuk mengetahui efektifitas pembelajaran mata kuliah akuntansi bisnis berbasis Micruled berbantuan e-learning yang valid untuk belajar mahasiswa. Populasi dalam dalam penelitian ini adalah seluruh mahasiswa semester III program studi komputerisasi akuntansi STEKOM Semarang. Penelitian ini merupakan penelitian eksperimen jenis Quasi Experimental (Samsudi, 2006: 75) yang bertujuan untuk meningkatkan prestasi belajar mahasiswa pada mata kuliah akuntansi bisnis yang memenuhi kriteria efektif. Diperoleh hasil penelitian: (1) Terdapat pengaruh positif keterampilan proses terhadap prestasi belajar mahasiswa yang ditunjukkan kontribusi pengaruhnya sebesar 55,6\%. (2) Prestasi belajar kelas eksperimen lebih tinggi dibanding prestasi belajar kelas kontrol yang ditunjukkan dengan rata - ratanya yaitu rata - rata kelas eksperimen sebesar 78 dan rata - rata kelas kontrol sebesar 65,7. Jadi berdasarkan hasil penelitian dan pembahasan penelitian diatas maka pembelajaran mata
\end{abstract}


kuliah akuntansi bisnis dengan Construktivist Learning Design berbantuan E-Learning pada mata kuliah akuntansi bisnis adalah efektif.

Kata kunci: Construktivist Learning Design., E-Learning, Akuntansi Bisnis

\section{PENDAHULUAN}

Pembelajaran mata kuliah akuntansi bisnis secara konvensional masih menempatkan dosen sebagai sumber informasi utama yang berperan dominan dalam proses pembelajaran. Dalam pembelajaran konvensional, dosen bertindak sebagai pentransfer ilmu, mahasiswa dianggap sebagai penerima pengetahuan yang pasif (Suparman, 1997:198). Pemahaman yang mereka miliki hanya pemahaman instrumental bukan pemahaman relasional (Skemp, 1976). Model pembelajaran konvensional menyebabkan mahasiswa tidak memberikan respon aktif yang optimal, karena mahasiswa dipaksa menerima pengetahuan dari dosennya tanpa mengetahui apa makna ilmu yang diperoleh tersebut (Marpaung, 2007:2).

Schramm (1984:39) mengatakan bahwa kemampuan mahasiswa menggunakan pengalaman atau pengetahuan yang telah mereka miliki untuk mengonstruk (membangun) pengetahuan yang baru sangat dipengaruhi media pembelajaran yang digunakan. Hal ini beralasan karena ada keyakinan bahwa penggunaan media pembelajaran yang melibatkan lebih dari satu indera pada diri mahasiswa akan lebih baik dari pada menggunakan media pembelajaran yang merangsang satu indera.

Salah satu solusi yang ditawarkan untuk menindaklanjuti permasalahan tersebut adalah konsep pembelajaran akuntansi melalui Construktivist Learning Design. Secara umum konstruktivisme yaitu mendorong kolaborasi, kegiatan penduhuluan dan eksplorasi, dan menekankan pemecahan masalah otentik (Gupta, 2008). Seiring berjalannya waktu saat ini berkembang
E-Learning. Rosenberg menekankan bahwa E-learning merujuk pada penggunaan teknologi internet untuk mengirimkan serangkaian solusi yang dapat meningkatkan pengetahuan dan keterampilan.

Sedangkan mata kuliah yang sangat cocok dengan Construktivist Learning Design adalah akuntansi bisnis untuk bekal mahasiswa menjadi seorang akuntan bisnis. Harapannya dengan pembelajaran berbantuan E-Learning mahasiswa lebih kreatif dan terampil dalam mencari informasi materi mata kuliah akuntansi bisnis. Selain itu, keterampilan mahasiswa dalam penggunaan teknologi dan proses pembelajaran semakin baik.

\section{Rumusan Masalah}

Berdasarkan latar belakang diatas, maka rumusan penelitian adalah:

a) Apakah terdapat pengaruh keterampilan proses pada pembelajaran berbantuan e-learning pada mata kuliah akuntansi bisnis terhadap prestasi belajar mahasiswa

b) Apakah pembelajaran berbasis Construktivist Learning Design berbantuan e-learning pada mata kuliah akuntansi bisnis lebih baik dari pembelajaran konvensional?

\section{Tujuan Penelitian}

Dari permasalahan yang telah dirumuskan, maka penelitian ini bertujuan untuk:

a) Untuk mengetahui pengaruh keterampilan proses pada pembelajaran matematika berbasis Construktivist Learning Design berbantuan e-learning pada mata akuntansi bisnis 
terhadap prestasi belajar mahasiswa.

b) Untuk mengetahui pembelajaran akuntansi bisnis berbasis Construktivist Learning Design berbantuan e-learning lebih baik dari pembelajaran konvensional.

\section{DASAR TEORI}

\section{Construktivist Learning Design}

Prinsip dasar yang mendasari filsafat konstruktivisme adalah semua pengetahuan dibangun dan bukan dipersepsi langsung oleh indera (Muijs dan Reynolds 2008: 96). Mahasiswa membangun pengetahuannya secara aktif karena belajar adalah sebuah pencarian makna. Dosen mendorong mahasiswa untuk membangun makna dengan menstrukturalisasikan berbagai gagasan dan eksplorasi, serta dapat menghubungkan pengetahuan baru yang dibangun dari pengetahuan yang telah dimilikinya (Kenny dan Wirth, 2009).

Menurut Hudojo (1998: 7-8), ciriciri pembelajaran dalam pandangan konstruktivisme adalah menyediakan pengalaman belajar dengan mengkaitkan pengetahuan yang telah dimiliki sehingga belajar merupakan proses pembentukan pengetahuan dan menyediakan berbagai alternatif pengalaman belajar. Selain itu, mengintegrasikan pembelajaran dengan situasi yang realistis dan relevan sehingga memungkinkan terjadinya transmisi sosial, memanfatkan berbagai media sehingga pembelajaran menjadi lebih efektif, dan melibatkan mahasiswa secara aktif, sehingga matematika menjadi menarik dan menyenangkan. Dalam penelitian ini akan dirancang desain pembelajaran kontruktivisme yang dikemas menjadi Contruktivisme Learning Design. Harapannya dengan Construktivist Learning Design pembelajaran akan menjadi lebih efektif.

\section{E-Learning}

E-Learning saat ini sedang banyak digunakan dalam pembelajaran. Menurut Darin E. Hartley, e-learning adalah suatu belajar mengajar yang memungkinkan tersampaikannya bahan ajar ke mahasiswa dengan menggunakan media internet, intranet, atau media jaringan komputer lain. Sedangkan menurut Martin Jenkins, e-learning adalah proses belajar yang difasilitasi dan didukung melalui pemanfaatan Teknologi Informasi dan Komunikasi (TIK). Jadi pembelajaran dengan bantuan internet dapat dikategorikan dalame-learning.

Blogspot merupakan salah satu kategori dalam E-Learning. Dengan blogspot mahasiswa dapat memanfaatkannya dalam mencari bahan ajar dan dengan bantuan proprofs mahasiswa dapat langsung online mengerjakan latihan soal dan sekaligus untuk soal ujiannya. Dalam penelitian ini akan menggunakan bantuan blogspot dan proprofs dalam pembelajaran berbasis Construktivist Learning Design.

\section{Ketrampilan Proses Mahasiswa}

Proses menurut Syah (2003 : 109) berarti cara-cara atau langkah-langkah khusus yang dengannya beberapa perubahan ditimbulkan hingga tercapainya hasil-hasil tertentu. Menurut Reber (Syah, 2003 : 121) keterampilan adalah kemampuan melakukan pola-pola tingkah laku yang kompleks dan tersusun rapi secara maksimal dan sesuai dengan keadaan untuk mencapai hasil tertentu. Jadi keterampilan proses dalam proses pembelajaran adalah suatu kecakapan yang diperoleh akibat langkah-langkah strategi pembelajaran sehingga terjadi perubahan tingkah laku.

\section{Prestasi Belajar}

Menurut Winkel (1991:42), prestasi belajar merupakan bukti keberhasilan 
yang telah dicapai mahasiswa di mana setiap kegiatan belajar dapat menimbulkan suatu perubahan yang khas. Prestasi belajar adalah keberhasilan yang diperoleh karena suatu usaha memperoleh ilmu, keberhasilan yang menjadi salah satu wujud dari usaha seseorang setelah memperoleh pengalaman belajar (Muhibbin, 2003).

\section{Penelitian yang Relevan}

Penelitian ini sejalan dengan penelitian Suparman (2011) menyatakan bahwa pembelajaran dengan media E-Learning dapat meningkatkan hasil belajar peserta didik. Menurut Guskey (1982) pembelajaran yang efektif ditandai dengan adanya ketercapaian ketuntasan dalam prestasi belajar, adanya pengaruh yang positif antara variabel bebas dengan variabel terikat, adanya perbedaan prestasi antara kelas eksperimen dengan kelas kontrol.

\section{METODE PENELITIAN}

1. Jenis Penelitian

Jenis penelitian ini adalah penelitian Quasi Experimental (Samsudi, 2006: 75) yang bertujuan untuk meningkatkan prestasi belajar mahasiswa pada mata kuliah akuntansi bisnis yang memenuhi kriteria efektif.

2. Variabel Penelitian

Variabel dalam penelitian ini adalah pembelajaran berbasis Construktivist Learning Design (x) ketrampilan proses dan hasil belajar (y)

3. Subjek Penelitian

Subjek dalam penelitian ini adalah media E-Learning pada materi kuliah akuntansi bisnis dengan responden para mahasiswa semester III sebanyak 2 kelas dari 3 kelas yang ada di Prodi komputerisasi akuntansi STEKOM Semarang.
4. Desain Penelitian

Desain penelitian eksperimen jenis Quasy Experimental

5. Teknik Pengumpulan Data

Instrumen penelitian adalah alat untuk mengumpulkan data tentang pembelajaran matematika berbasis Construktivist Learning Design berbantuan E-Learning pada mata kuliah akuntansi bisnis. Instrumen pada penelitian ini terdiri dari lembar pengamatan keterampilan proses mahasiswa dan lembar tes prestasi belajar.

6. Teknik Analisis Data

Data dari variabel keterampilan proses diambil dengan pengamatan, sedangkan data dari variabel prestasi belajar diambil dengan tes. Data yang diperoleh diolah dengan analisis inferensial. Suatu pembelajaran dikatakan efektif jika memenuhi ketercapaian pengukuran ketuntasan belajar, adanya pengaruh variabel bebas terhadap variabel terikat, ada perbedaan antara prestasi belajar mahasiswa pada kelas eksperimen lebih tinggi dibandingkan prestasi belajar pada kelas kontrol.

\section{HASIL DAN PEMBAHASAN}

Berdasarkan hasil pengujian homogenitas dan normalitas dapat dikatakan bahwa kelas IIIA dan kelas IIIB adalah kelas yang homogen dan berdistribusi normal. Pelaksanaan penelitian ini diberikan dalam 5 kali pertemuan untuk proses pembelajaran pada kelas eksperimen dan 1 kali pertemuan untuk tes prestasi belajar pada kelas eksperimen dan kelas kontrol. Pembelajaran diampu oleh dosen yang mengampu mata kuliah akuntansi bisnis. Selanjutnya penelitian dilakukan pada kelas eksperimen. Hasil penelitian terdiri dari data hasil pengamatan keterampilan proses mahasiswa, data tes prestasi belajar (TPB) di kelas 
eksperimen dan data tes prestasi belajar (TPB) di kelas kontrol. Selain itu dalam penelitian ini juga dilakukan uji coba soal yang berjumlah 10 soal yang kemudian setelah dilakukan uji validitas, uji reliabilitas, uji tingkat kesukaran dan uji daya beda diambil 4 soal yaitu soal nomor 1, 4, 6 dan 9 . Data-data tersebut selanjutnya dianalisis untuk diketahui ketuntasannya, besar pengaruh, dan kemampuan membedakan antara kelas eksperimen dan kelas kontrol. Pembahasan penelitian tersebut dapat dijelaskan sebagai berikut.

\section{Pengaruh Variabel Bebas terhadap Variabel Terikat}

Pada pembahasan ini akan dilihat pengaruh variabel bebas yang dalam penelitian ini yaitu keterampilan proses terhadap variabel terikat yaitu tes prestasi belajar. Keterampilan proses dalam proses pembelajaran adalah suatu kecakapan yang diperoleh akibat langkah-langkah strategi pembelajaran sehingga terjadi perubahan tingkah laku. Widyatiningtyas (2010: 1) menyatakan bahwa mahasiswa melaksanakan keterampilan proses maka akan sekaligus dikembangkan sikap-sikap yang dikehendaki seperti kreatif, kerjasama, bertanggung jawab, dan berdisplin sesuai dengan penekanan bidang studi yang bersangkutan. Dengan demikian, keterampilan proses merupakan proses pembelajaran yang mengarah kepada pengembangan kemampuan-kemampuan mental, fisik, dan sosial yang mendasar sebagai penggerak kemampuan yang lebih tinggi dalam diri individu mahasiswa. Karena itu peningkatan keterampilan proses pada mahasiswa merupakan hal penting yang harus selalu diupayakan agar peningkatan prestasi belajar mahasiswa dapat tercapai secara optimal. Berdasarkan analisis uji pengaruh, telah dapat dibuktikan bahwa keterampilan proses berpengaruh secara linear terhadap prestasi belajar mahasiswa.

Melalui pembelajaran matematika berbasis Construktivist Learning Design berbantuan E-Learning, dihasilkan pengaruh keterampilan proses terhadap prestasi belajar sebesar $55,6 \%$.

\section{Perbedaan Kelas Eksperimen dengan Kelas Kontrol}

Berdasarkan hasil membandingkan nilai rata-rata kelas eksperimen dan kelas kontrol dapat disimpulkan bahwa kelas eksperimen mempunyai nilai ratarata ketuntasan lebih tinggi dibandingan nilai rata-rata ketuntasan kelas kontrol. Ini menunjukkan pembelajaran Construktivist Learning Design berbantuan E-Learning yang lebih menekankan pada keterampilan mahasiswa dalam mengonstruk permasalahan yang ada dan mahasiswa dapat mengakses materi di blog serta bisa langsung melakukan tes online terbukti lebih baik dari pembelajaran dengan metode konvensional yang selama ini dilakukan.

Di sisi lain, dengan proses pembelajaran berbasis Construktivist Learning Design berbantuan E-Learning sangat mungkin berlangsung secara optimal karena proses pembelajaran dapat benar-benar terjadi. Pembelajaran menggunakan Construktivist Learning Design berbantuan E-Learning yang dilakukan pada kelas eksperimen mempunyai kecenderungan keterkaitan yang lebih kuat dibandingkan pembelajaran yang dilakukan pada kelas kontrol.

Dari ketiga komponen ini terbukti bahwa pembelajaran Construktivist Learning Design berbantuan E-Learning pada mata kuliah akuntansi bisnis 
memenuhi tiga hal yaitu : (1) ada pengaruh keterampilan proses terhadap prestasi belajar; (2) prestasi belajar kelas eksperimen lebih baik dari kelas kontrol. Menurut Guskey karena telah memenuhi 2 hal diatas maka pembelajaran tersebut mencapai efektif. Hasil penelitian ini sejalan dengan hasil penelitian Bahbahani (2006) yang menyatakan bahwa penggunaan konstruktivisme dalam pembelajaran mempengaruhi prestasi, motivasi dan aktualisasi diri mahasiswa. Melalui pembelajaran konstruktivisme, mahasiswa ditempa, sehingga memahami teori, latihan, dan dapat mengaplikasikan teori dan latihan tersebut dalam dunia nyata di kampus. Hasil yang sama juga diperoleh pada penelitian Tasfirani (2008), Sulistyono (2009) dan Arif (2010).

Jadi berdasarkan hasil penelitian dan pembahasan penelitian diatas maka pembelajaran matematika Construktivist Learning Design berbantuan E-Learning pada mata kuliah akuntansi bisnis adalah efektif.

\section{PENUTUP}

\section{Simpulan}

Berdasarkan hasil penelitian yang telah diuraikan maka diperoleh kesimpulan bahwa pelaksanaan pembelajaran akuntansi bisnis dengan Construktivist Learning Design berbantuan E-Learning telah mencapai indikator efektif, yaitu:

a) Terdapat pengaruh positif keterampilan mahasiswa terhadap prestasi belajar mahasiswa yang ditunjukkan kontribusi pengaruhnya sebesar 55,6 $\%$.

b) Prestasi belajar kelas eksperimen lebih tinggi dibanding prestasi belajar kelas kontrol yang ditunjukkan dengan rata- ratanya yaitu rata - rata kelas eksperimen sebesar 78 dan rata - rata kelas kontrol sebesar 65,7 .

\section{Saran}

Berdasarkan kesimpulan yang telah dikemukakan dapat diajukan beberapa saran untuk kemajuan lebih lanjut sebagai berikut:

a) Disarankan e-learning dapat digunakan bagi dosen-dosen yang mengampu mata kuliah akuntansi bisnis

b) Perlu dilakukan perbaikan lagi untuk desain e-learning berbasis blog tersebut yang didalamnya mampu membuat mahasiswa lebih aktif lagi menggunakannya dalam pembelajaran mata kuliah akuntansi bisnis.

\section{DAFTAR PUSTAKA}

Baharudin dan Wahyuni, 2008. Teori Belajar dan Pembelajaran. Yogyakarta : Ruzz Media.

Paulus. 2012. Pengantar Teknologi dan Komunikasi (TIK). Semarang : STEKOM Semarang Press.

Gupta, A. 2008. Constructivism and Peer Collaboration in Elementary School: The Connection to Estimology. Eurasia Journal of Education, vol. 4, no.4, 381386.

Guskey et al. 1983. The Effectiveness of Mastery Learning Strategies in Undergraduate Educations Courses. Journal of Educational Research, vol.76, No. 4, 210-214.

Isjoni, Ismail, dan Mahmud. 2008. ICT Untuk Sekolah Unggul. Yogyakarta: Pustaka Pelajar. 
Marpaung, Y. 2007. Pendekatan Multikultural Dalam Pembelajaran. UNY Press.

Muhibbin, S. 2003. Psikologi Belajar. Jakarta: Raja Grafindo Persada.

Mulyana, E. 2004. Kurikulum Berbasis Kompetensi, Bandung; PT. Remaja Rosdakarya.

Muijs dan Reynold. 2008. Effective Teaching: Teori dan Aplikasi. Yogyakarta : Pustaka Pelajar.

Piaget, J. 1973. The Child and Reality (W. Mays, Trans). London: Routledge \& Kegan Paul.

Samsudi. 2009. Disain Penelitian Pendidikan. Semarang: UNNES PRESS.

Schramm, 1984. Media Besar Media Kecil, Alat dan Teknologi untuk Pengajaran, Seri Pustaka Teknologi Pendidikan No. 5. IKIP Semarang.
Skemp, R. R., 1976. Relational Understanding and Instrumental Understanding. In Mathematics Teaching, No. 77.

Suparman, A. Dkk. 2011. Implementasi Pembelajaran ekonomi Dengan Media E-Learning Materi Anuitas Kelas X Semester II SMA Walisongo Semarang. Semarang: Universitas Terbuka.

Syah, M. 2003. Psikologi Belajar. Semarang: Laboratorium Komputer Pasca Sarjana UNNES.

Vygotsky. 1978. Characteristics of Constructivist Learning and Teaching. http:www.stemnet.nf.ca (26/11/2009).

Winkel, W.S. 2004. Psikologi Pengajaran. Yogyakarta: Media Abadi 